\title{
Employee Performance Analysis: The Influence of Local Wisdom-Based Communication Strategy And Employee Engagement on Employee Performance
}

\author{
Yasmin Chairunisa Muchtar ${ }^{1, *}$ Linda Trimurni Maas ${ }^{2}$ \\ ${ }^{1,2}$ Universitas Sumatera Utara \\ "Corresponding author. Email: yasminmuchtar@usu.ac.id
}

\begin{abstract}
Good communication is an important tool in improving the quality of superior performance and maintaining good working relationships within the organization. In the District of Samosir, a communication strategy that incorporates elements of local wisdom will strengthen employee engagement, which in turn will encourage employee performance. The study aims to analyze the effect of local wisdom-based communication strategy on employee performance, mediated by employee engagement. This research was carried out in Samosir District, Province of Sumatera Utara. The objects in this study were 107 districts, government employees. Results show that employee engagement served as the mediator between local wisdom-based communication strategy and employee performance.
\end{abstract}

Keywords: Local Wisdom-Based Communication Strategy, Employee Engagement, Employee Performance, Dalihan Na Tolu

\section{INTRODUCTION}

An employee is considered as one of the most important elements for the organization [1], the key success factors of the organization. Employee performance can be considered the backbone of organizational performance. Therefore, organizations are investing a huge amount of effort in exploring employee performance. However, in today's world, it is still a big challenge for the organization to find out the most fitted factors to encourage the employees to achieve their best performance. While being engaged in their job.

It happens as well in the District Office of Samosir, Sumatera Utara Province. There are various efforts were conducted to achieve better employees performance. According to [17] employee performance can be explained from the internal communication strategy in the org. In addition, Internal communication can create employee engagement which will lead to greater performance.

District of Samosir which is famous as the birthplace of the Batak tribe, uses Batak Toba culture and customs in daily life. Therefore in order to achieve employee engagement and greater performance, the District office of Samosir incorporates the local wisdom from Batak Toba culture in the internal communication strategy.
The practices of local wisdom namely Dalihan Na Tolu in the internal communication strategy in the District Office of Samosir is suitable due to the characteristics of its location and employees. Batak people originated from Pusuk Buhit in the District of Samosir and scattered all over the area of Indonesia. Therefore, people in Samosir strongly maintain the customs and cultures based on The Batak tradition which was inherited by the older generation.

Although several studies have discussed the relationship between internal communication strategy with employee engagement and employee performance, there was a very limited study that has analyzed the concept of an internal communication strategy that incorporates the local wisdom. Hence, this study tries to fill the research gap and enrich the body of knowledge related to internal communication strategy on employee engagement and employee performance, by analyzing the effect of local wisdom-based communication strategy on employee performance mediated by employee engagement.

\section{LITERATURE REVIEW}

\subsection{Local Wisdom-based Communication Strategy}

One of the local community cultures that need to be preserved is local wisdom. According to [2], 
local wisdom can be defined as a local knowledge applied by local communities that blended with not only belief systems but also norms, and cultures. Local wisdom is demonstrated in lifelong traditions and myths.

The widely known local wisdom in the Batak Toba community is Dalihan Na Tolu or Tungku Nan Tiga. This value serves as a guide that regulates, controls, and gives direction to the behavior and deeds (attitude or pattern of action) of the Batak Toba people. Dalihan $\mathrm{Na}$ Tolu means the three pillars of the furnace. The three furnaces of Dalihan [3] are symbols of Hula-hula, Dongan Sabutuha, and Boru. The philosophy of Dalihan $\mathrm{Na}$ Tolu supports equality, as important as one another. Everything is equal, there is no discrimination, there is no distinction between religion, race, or class.

The organization's internal communication strategy based on local wisdom incorporates the philosophy of Dalihan $\mathrm{Na}$ Tolu in internal communication within the organization. The application of Dalihan $\mathrm{Na}$ Tolu philosophy in an internal communication strategy is appropriate because the characteristics of employees at the Toba Samosir Government Office are highly concerned with preserving and upholding Batak customs in their daily life. Based on the existing organizational structure, the manager acts as a Hula-Hula that protects employees. Employees act as Boru, who work in the organization under the supervision and direction of Hula-Hula. Meanwhile, the relationship between colleagues at the employee level represents mutual respect namely 'Dongan Sabutuha', which promotes the existence of understanding among them.

Each element of Dalihan $\mathrm{Na}$ Tolu is obliged to uphold the role and show respect based on their respective positions. The existence of these three elements in Dalihan $\mathrm{Na}$ Tolu cannot be separated and are interdependent. Under any circumstances, all three have the same obligation to help and provide solutions to existing problems. Providing input is also in accordance with the capacity or role of each element and is carried out through a deliberation process.

In practice, the philosophy of Dalihan $\mathrm{Na}$ Tolu is not similar to the common traditional concept that uses a top-down approach but upholds equality which is based on the symbolism of the three furnaces that cannot stand alone. This concept fits perfectly with symmetrical internal communication, which promotes trust, openness, credibility, two-way communication, and negotiation within the organization [4].

Dalihan $\mathrm{Na}$ Tolu enriches the internal communication strategy to encourage a better quality of employee relations.

\subsection{Employee Engagement}

Employee engagement has arisen as a significant factor of current business development. It influences the morale of the employee, the level of productivity, and reasons for retaining in the organization. Generally, organizations use their engaged employees as a way to achieve strategic competence. An employee with a high level of engagement towards the organization is more likely will excel at the standard of performance [5].

There are various definitions of employee engagement. The first construct was proposed by [6], as participating one's "favored self" and as "...the connection of themselves with their work roles; in engagement, people demonstrate their physical, cognitive, and emotional effort during role performances" (p. 694)

Refer to [7], employee engagement was described as the involvement of an individual's thorough identification with his or her work, embracing many factors, namely (1) passion (full of energy, enthusiasm, and toughness), (2) commitment (indepth connection with the job including significance, motivation, and challenge), and, (3) absorption (being fully participated with work tasks).

It is noticeable that engaged employees put a lot of effort toward their main job tasks, responsibilities, and extra-role behaviors. An engagement is viewed as a distinct construct in relation to other organizational behavior variables, partially because there is the involvement of an individual's working experience, its impacts on the performance of rather than just work attitudes related to performance [8]

\subsection{Employee Performance}

Employee performance can be explained as an employee's behavior when performing a job or task [9]. It is the product or outcome resulted by the employees in the organization [10]. Employee performance embraces the employee's achievement in line with the regulations, expectations, and requirements of the organization. The set of ability, effort and perception of the task from employees can produce employee performance. [11], [12]. 
In terms of organizational context, employee performance is the degree of contribution of an organizational member in achieving the organizational goals [13].

\subsection{Local Wisdom-based Communication Strategy, Employee Engagement, and Employee Performance}

Communication has significance role in employee engagement [14], [15], [16]. [16] highlight the needs of employees to have clear communication from superiors, in order to relate their roles with leadership vision. In addition, internal communication is an important activity in an organization because it helps individuals and groups to achieve goals. Effective internal communication plays an essential role in improving performance [17].

The organization can successfully convey the values to all employees through a local wisdombased communication strategy, which will lead to the support delivered by the employees toward the organizational goals. Dalihan $\mathrm{Na}$ Tolu and symmetrical communication as the foundation of communication strategy in the organization will improve the level of employee engagement. The feeling of trust, openness, and interdependency between employees and organization create the favorable condition for the development of their connections with their works and organization. Therefore, internal communication is important to guarantee employee engagement [18], [19], [20].

Previous studies found that employee engagement has a relationship with greater employee performance, which further leads to enhanced organizational performance, in terms of [21], [22]. Therefore, the relationship between local wisdombased communication strategy and employee performance is significant through the role of employee engagement.

Hypothesis: Local Wisdom-based Communication Strategy is positively related to Employee Performance mediated by Employee Engagement.

\section{METHODOLOGY}

\subsection{Research Methodology}

This research was conducted at BPKPD Kabupaten Samosir, while the objects in this study were 107 employees at BPKPD Kabupaten Samosir. To test the validity and fit of the model, use the Loading Factor and Average Variance Extracted (AVE). The hypothesis are tested by using Structural Equation Model (SEM) method.
This study uses a five-point Likert scale measures, whereby 1 represents for strongly disagree and strongly agree is represented by 5 . All the measurements were adapted from the existing literature and demonstrated with good levels of reliability and validity. Local Wisdom-based Communication Strategy (6-item) was operationalized by adapting from by [23] and incorporate the philosophy of Dalihan $\mathrm{Na}$ Tolu. Employee engagement (10-item) was operationalized by adopting from [24]. Employee performance (9-item) was operationalized by adapting from [25].

\section{RESULTS AND DISCUSSION}

\subsection{Results}

\subsubsection{Validity Test}

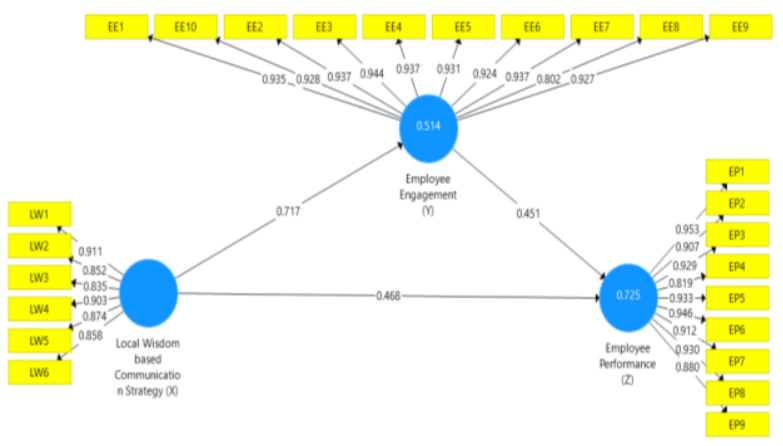

Figure 1. Validity Testing based on Loading Factor

The validity testing from figure 1 shows the that is demonstrated the entire loading value is $>0.7$. It can be concluded that all requirements are achieved.

Table 1. The Value of Validity Testing according to Average Variance Extracted.

\begin{tabular}{|l|c|}
\hline & (AVE) \\
\hline Employee Engagement (Y) & 0.848 \\
\hline Employee Performance (Z) & 0.834 \\
\hline $\begin{array}{l}\text { Local Wisdom-based } \\
\text { Communication Strategy (X) }\end{array}$ & $\mathbf{0 . 7 6 1}$ \\
\hline
\end{tabular}

Based on the table 1, all the requirement for the validity are met, which are $>0.5$ [26]. Furthermore, reliability testing was carried out based on the composite reliability $(\mathrm{CR})$ value.

\subsection{Measures}


Table 2. The Testing of Reliability

\begin{tabular}{|l|c|}
\hline & $\begin{array}{c}\text { The Composite } \\
\text { Reliability }\end{array}$ \\
\hline Employee Engagement (Y) & $\mathbf{0 . 9 8 2}$ \\
\hline Employee Performance (Z) & $\mathbf{0 . 9 7 8}$ \\
\hline $\begin{array}{l}\text { Local Wisdom-based } \\
\text { Communication Strategy (X) }\end{array}$ & $\mathbf{0 . 9 5 0}$ \\
\hline
\end{tabular}

According to table 2, the recommended CR value is above 0.7 [26]. Meaning that the requirement of validity has been fulfilled $\mathrm{CR}$ values are > 0.7 , which means that they have met the validity requirements based on the $\mathrm{CR}$.

Table 3 Reliability Testing based on Cronbach's Alpha (CA)

\begin{tabular}{|l|c|}
\hline & Cronbach's Alpha \\
\hline Employee Engagement (Y) & $\mathbf{0 . 9 8 0}$ \\
\hline Employee Performance (Z) & $\mathbf{0 . 9 7 5}$ \\
\hline $\begin{array}{l}\text { Local Wisdom-based } \\
\text { Communication Strategy (X) }\end{array}$ & $\mathbf{0 . 9 3 7}$ \\
\hline
\end{tabular}

In table 3 , it is clear that the recommended CA should be value is above 0.7 [27]. It can be noticed the overall value of $\mathrm{CA}$ above the lower limit of 0.7 .

Table 4. The Test of Discriminant Validity

\begin{tabular}{|l|c|c|c|}
\hline & $\begin{array}{c}\text { Employe } \\
\text { e } \\
\text { Engagem } \\
\text { ent (Y) }\end{array}$ & $\begin{array}{c}\text { Employe } \\
\text { e } \\
\text { Performa } \\
\text { nce (Z) }\end{array}$ & $\begin{array}{c}\text { Local } \\
\text { Wisdom- } \\
\text { based } \\
\text { Communicati } \\
\text { on Strategy } \\
\text { (X) }\end{array}$ \\
\hline $\begin{array}{l}\text { Employee } \\
\text { Engagement (Y) }\end{array}$ & 0.921 & & \\
\hline $\begin{array}{l}\text { Employee } \\
\text { Performance (Z) }\end{array}$ & 0.787 & 0.913 & \\
\hline $\begin{array}{l}\text { Local Wisdom- } \\
\text { based } \\
\text { Communication } \\
\text { Strategy (X) }\end{array}$ & 0.717 & 0.791 & 0.873 \\
\hline
\end{tabular}

In discriminant validity testing as illustrated in table 4, the value of the square root of the AVE of a latent variable is compared with the correlation value between the latent variable and other latent variables. It is known that the square root value of AVE for each latent variable is greater than the correlation value between the latent variable and other latent variables. So it is concluded that it has met the requirements of discriminant validity.

\subsubsection{Bootstrapping}

Table 5 presents the results of the Significance Effect Test

Table 5. Significance Effect Test

\begin{tabular}{|l|c|c|c|c|c|}
\hline & $\begin{array}{c}\text { Origin } \\
\text { al } \\
\text { Sampl } \\
\text { e (O) }\end{array}$ & $\begin{array}{c}\text { Samp } \\
\text { le } \\
\text { Mean } \\
\text { (M) }\end{array}$ & $\begin{array}{c}\text { Standa } \\
\text { rd } \\
\text { Deviati } \\
\text { on } \\
\text { (STDE } \\
\text { V) }\end{array}$ & $\begin{array}{c}\text { T } \\
\text { Statistics } \\
\text { (|O/STDE } \\
\text { V|) }\end{array}$ & $\begin{array}{c}\text { P } \\
\text { Valu } \\
\text { es }\end{array}$ \\
\hline $\begin{array}{l}\text { Employee } \\
\text { Engagement } \\
\text { (Y)-> } \\
\text { Employee } \\
\text { Performance } \\
\text { (Z) }\end{array}$ & 0.451 & 0.429 & 0.155 & 2.904 & 0.004 \\
\hline $\begin{array}{l}\text { Local } \\
\text { Wisdom- } \\
\text { based } \\
\text { Communicat } \\
\text { ion Strategy } \\
\text { (X) -> } \\
\text { Employee } \\
\text { Engagement } \\
\text { (Y) }\end{array}$ & 0.717 & 0.716 & 0.094 & 7.647 & 0.000 \\
\hline $\begin{array}{l}\text { Local } \\
\text { Wisdom- } \\
\text { based } \\
\text { Communicat } \\
\text { ion Strategy } \\
\text { (X) -> } \\
\text { Employee } \\
\text { Performance } \\
\text { (Z) }\end{array}$ & 0.468 & 0.490 & 0.147 & 3.182 & 0.002 \\
\hline
\end{tabular}

Based on the results in Table 5 above, it can be highlighted several necessary information

- It is known that the coefficient of Employee Engagement (y) on Employee Performance (z) is 0.451 (original sample column), with P-Values = $0.004<0.05$, it is noticeable that Employee Engagement (y) significant effect on Employee Performance $(\mathrm{z})$

- It is known that the coefficient value of Local Wisdom-based Communication Strategy ( $\mathrm{x}$ ) on Employee Engagement (y) is 0.717 (original sample column), with P-Values $=0.000<0.05$, it is concluded that Local Wisdom-based Communication Strategy (x) affects significantly to Employee Engagement (y).

- It is known that the path coefficient value of local wisdom-based communication strategy $(\mathrm{x})$ on employee performance $(\mathrm{z})$ is 0.468 (original sample column), with P-Values $=0.002<0.05$, it is concluded that local wisdom-based communication strategy $(\mathrm{x})$ affects significantly to employee performance $(\mathrm{z})$ 
Table 6. Coefficient of Determination (R-Square)

\begin{tabular}{|l|c|}
\hline & R Square \\
\hline Employee Engagement (Y) & 0.514 \\
\hline Employee Performance (Z) & 0.725 \\
\hline
\end{tabular}

Based on the results in Table 6 , the value of $r$ square of employee engagement (y) is 0.514 . This value can be interpreted that the influence of local wisdom-based communication strategy $(\mathrm{x})$ on employee engagement (y) is $51.4 \%$. Meanwhile, the coefficient of determination (r-square) of employee performance $(\mathrm{z})$ is 0.725 . This value can be interpreted as the influence of local wisdombased communication strategy $(\mathrm{x})$ and employee engagement $(\mathrm{y})$ on employee performance $(\mathrm{z})$ of $72.5 \%$.

Table 7. Meditation Test

\begin{tabular}{|l|c|c|c|c|c|}
\hline & $\begin{array}{c}\text { Origin } \\
\text { al } \\
\text { Sampl } \\
\text { e (O) }\end{array}$ & $\begin{array}{c}\text { Mean } \\
\text { of } \\
\text { Sampl } \\
\text { e (M) }\end{array}$ & $\begin{array}{c}\text { STDE } \\
\text { V }\end{array}$ & $\begin{array}{c}\text { T } \\
\text { Statisti } \\
\text { cs } \\
(\mid \mathbf{O} / \mathbf{S T} \\
\text { DEV|) }\end{array}$ & $\begin{array}{c}\text { P } \\
\text { Valu } \\
\text { es }\end{array}$ \\
\hline $\begin{array}{l}\text { Local } \\
\text { Wisdom } \\
\text { based } \\
\text { Communic } \\
\text { ation }\end{array}$ & & & & & \\
$\begin{array}{l}\text { Strategy } \\
\text { (X) -> }\end{array}$ & 0.323 & 0.306 & 0.115 & 2.811 & 0.00 \\
$\begin{array}{l}\text { Employee } \\
\text { Engageme } \\
\text { nt (Y) -> } \\
\text { Employee } \\
\text { Performan } \\
\text { ce (Z) }\end{array}$ & & & & & 5 \\
\hline
\end{tabular}

Based on the results of the mediation test in Table 7 , it is known that the influence of local wisdombased communication strategy (x) on employee performance $(\mathrm{z})$ through employee engagement $(\mathrm{y})$ is 0.323 , with P-Values $=0.005<0.05$, it can be concluded that employee engagement $(y)$ is significant as a mediator of the relationship between local wisdom-based communication strategy (x) and employee engagement (y).

\subsection{Discussion}

This research aims to analyze the role of employee engagement in mediating the relationship between local wisdom-based communication strategy and employee performance. Based on the results of the study, it was found that employee engagement serves as the mediator between local wisdom-based communication strategy and employee performance. Employee performance is an employee's behavior when performing a job or task, as an achievement that is in line with the regulations, expectations, and requirements of the organization. This expected performance can be achieved when the employee has a strong involvement with his or her work, passion, enthusiast, and have a high commitment to the job tasks [7]. An engaged employee will have high responsibilities and put a lot of effort to excel in their job. Employee engagement was created from the existence of effective communication in the organization [14]. Added by [16], the need of employees to have clear communication from superiors, in order to relate their roles with leadership vision is the important factor to build employee engagement. Local wisdombased communication strategy characterized by the value of respect, protection, trust, openness, and equality will create a favorable atmosphere for employees to share their ideas, consult their problems, express their needs, and receives feedback. Superior acts as The Hula-Hula who protects The Boru, and Boru will give his or her outstanding performance under the supervision and direction of Hula-Hula. While colleagues serve as Dongan Satubu will consult with Hula-Hula if there is a conflict with Boru. Therefore, it can be stated that an internal communication strategy based on Dalihan $\mathrm{Na}$ Tolu encourages employees to engage with the job and organization, which will lead to high performance.

\section{AUTHORS' CONTRIBUTIONS}

LTM carried out the literature survey and study design. YCM participated in the quantitative analysis analysis and manuscript. Both authors have read and approved the final manuscript.

\section{ACKNOWLEDGMENTS}

We would like to express our appretiation big thanks gratitude to Universitas Sumatera Utara for the opportunity and the research funding through the TALENTA Grants 2021. Furthermore, we would like to express our appreciation for the assistance given by the Research Institute of Universitas Sumatera Utara. This research is very useful to increase our competence and careers as lecturers at Universitas Sumatera Utara.

\section{REFERENCES}

[1] Kim, J.-N. and Rhee, Y. (2011), "Strategic thinking about employee communication behavior (ECB) in public relations: testing the models of megaphoning and scouting effects in Korea", Journal of Public Relations Research, Vol. 23 No.
3 ,

10.1080/1062726x.2011.582204. 
[2] Sumarmi and Amirudin. (2014). Pengelolaan Lingkungan Berbasis Kearifan Lokal, Yogyakarta: Aditya Media.

[3] Gultom, Rajamarpodang, Dj. (1992). Dalihan Na Tolu: Nilai Budaya Batak. Medan: Armanda

[4] Grunig, J.E. (2001). "Two-way symmetrical public relations: past, present, and future", in Heath, R.L. (Ed.), Handbook of Public Relations, Sage, Thousand Oaks, CA, pp. 11-32.

[5] Harter J.K., Schmidt F.L., and Hayes, T.L. (2002). 'Business unit level relationship between employee satisfaction, employee engagement, and business outcomes: a meta-analysis. Journal of Applied Psychology. 87(2). 268-279

[6] Kahn, W. A. (1990). Psychological conditions of personal engagement and disengagement at work. Academy of Management Journal, 33(4), 692e724.

[7] Schaufeli, W. B., Salanova, M., Gonzalez-Roma, V., \& Bakker, A. B. (2002). The measurement of engagement and burnout: A two sample confirmatory factor analytic approach. Journal of Happiness Studies, 3(1), 71e92.

[8] Saks, A. M. (2011). Workplace spirituality and employee engagement. Journal of Management, Spirituality \& Religion, 8(4), 317e340.

[9] El-Zeiny, R. M. A. (2012) "The interior design of the workplace and its impact on employees' performance: A case study of the private sector corporations in Egypt," Procedia - Social and Behavioral Sciences, vol. 35, pp. 746-756. Available:

https://doi.org/10.1016/j.sbspro.2012.02.145.

[10] Adewale, A. J., Abodunde, S. M., Folorunso, O. O. (2014). "Exploring the effect of organizational commitment dimensions on employee performance: An empirical evidence from the academic staff of oyo state-owned tertiary institutions, Nigeria," International Journal of Academic Research in Business and Social Sciences, vol. 4(8), pp. 275-286.

[11] Hee, O.C., Cheng, T.Y., Yaw, C.C., Gee, W.V., Kamaludin, S.M., Prabhagaran, J.R. (2016). "The Influence of Human Resource Management Practices on Career Satisfaction: Evidence from Malaysia," International Review of Management and Marketing, vol. 6(3), pp. 517-521.

[12] Ping, L.L., Ahmad, U.N.U., Hee, O.C. (2016). "Personality traits and customer-oriented behavior of the Malaysian nurses," International Business Management, vol. 10(13), pp. 2579-2584.
[13] Williams, L.J. and Anderson, S.E. (1991), "Job satisfaction and organizational commitment as predictors of organizational citizenship and in-role behaviors", Journal of management, Vol.17No. 3, pp.601-617

[14] Wiley, J.W., Kowske, B.J. and Herman, A.E. (2010). Developing and validating a global model of employee engagement. in Albrecht, S.L. (Ed.). Handbook of Employee Engagement: Perspectives, Issues, Research, and Practice. Edward Elgar. Cheltenham.

[15] Kahn, W.A. (1992). "To be fully there: psychological presence at work". Human Relations. Vol. 45. No. 4. pp. 321-49.

[16] MacLeod, D. and Clarke, N. (2009). The MacLeod Review - Engaging for Success: Enhancing Performance through Employee Engagement. Department for Business Innovation and Skills. London, Crown Copyright.

[17] Berger, B. (2008). Employee = organizational communications. Institute for Public Relations. Gainesville, FL: Institute for Public Relations. Retrieved from: http://www.instituteforpr.org/topics/employeeorganizational-communications/

[18] Bindl, U.K. and Parker, S.K. (2010). "Feeling good and performing well? Psychological engagement and positive behaviors at work". In Albrecht, S.L. (Ed.).Handbook of Employee Engagement: Perspectives, Issues, Research, and Practice. Edward Elgar. Cheltenham.

[19] Bakker, A.B., Hakanen, J.J., Demerouti, E. and Xanthopoulou, D. (2007). "Job resources boost work engagement, particularly when job demands are high". Journal of Psychology. Vol. 99. No. 2. pp. 274-84.

[20] Welch, M. (2011). The evolution of the employee engagement concept: Communication implications. Corporate Communications: An International Journal, Vol.16. Issue: 4. pp.328-346.

[21] Tower, P. (2006). Ten steps to creating an engaged workforce: key European findings. Towers Perin HR Services.

[22] Gallup. (2006). 'Gallup study: engaged employees inspire company innovation: national survey finds that passionate workers are most likely to drive organizations forward', The Gallup Management Journal, accessed at http://gmj.gallup.com/content/24880/Gallup-StudyEngaged-Employees-Inspire-Company.aspx 
[23] Dozier, D. M., Grunig, L. A., \& Grunig, J. E. (1995). Manager's guide to excellence in public relations and communication management. Mahwah, NJ: Lawrence Erlbaum Associates.

[24] Rich, B., Lepine, J., \& Crawford, E. (2010). Job engagement: Antecedents and effects on job performance. Academy of Management Journal, 53(3), 617e635.

[25] Abelsen, B., Gaski, M., Brandstorp, H. (2015). "HRM, communication, satisfaction, and perceived performance: A cross-level test," Journal of Management, vol. 39(6), pp. 1637-1665.

[26] Fornell, C. \& Larcker, D. F. (1981). Evaluating structural equation models with unobservable variables and measurement error. Journal of marketing research, 39-50.

[27] Nunnally JC. (1978). Psychometric theory. New York: McGraw Hill. 